Так, навчання композиції в іiі творчому житті завжди поєднувалося із музично-теоретичною освітою. Як композиторка вона навчалася у класі професора Київської консерваторії Генадія Ляшенка, як науковиця - у класі українського теоретика Дмитра Терентьєва, під керівництвом якого В. Тормахова захистила дисертацію у 2007 році.

Обробки В. Тормахової майстерно демонструють безліч варіантів поєднання скарбів національної музики 3 елементами джазової стилістики. Такий симбіоз не $\epsilon$ простим механічним доданком ознак класичного джазу з відомими народними мелодіями, це, скоріше, вияв джазового мислення в органічному контексті фольклорного мелосу. Джазова стилістика вдало розкриває різні акценти сюжетних ліній народного тексту і за рахунок яскравої альтерованої акордики, бітбоксу, імпровізацій, свінгування, динамізує їх плинну статику, закладену каноном повторності у традицію народного співу.

\title{
Література:
}

1. Саратський О. Цвіте терен [Ноти]: джазові обробки українських народних пісень для фортепіано. Частини I та II. Київ : Муз. Україна, $2017.60 \mathrm{c}$.

2. Хрестоматія для чоловічого вокального ансамблю а капела: нотна збірка [упоряд. та заг. ред. В. М. Тормахова]. Київ : Видавництво Ліра-К, 2020. $180 \mathrm{c}$.

DOI https://doi.org/10.30525/978-9934-26-004-9-17

\section{КЛАВІРНІ КОНЦЕРТИ Й. ГАЙДНА: АВТОРСТВО ТА ВИКОНАВСЬКА ВАРІАНТНІСТЬ}

\author{
Соловйова О. А. \\ аспірант кафедри образотворчого мистецттва, \\ музикознавства та культурологіі \\ Сумського державного педагогічного університету \\ імені А. С. Макаренка \\ м. Суми, Україна
}

Пріоритетні жанри віденського класицизму - симфонія, концерт, соната стали провідними в творчості його засновника Йозефа Гайдна. Майже тридцять років його життя було пов'язано зі службою в відомій 
капелі славетного, знатного та багатого угорського роду Естергайзі. Композитор мав в своєму постійному розпорядженні оркестр і змогу удосконалювати свою майстерність як оркестровщика, відточувати форму своїх творів, таким чином, він досяг таких результатів, які дозволяють його композиторський досвід вважати створенням високих стандартів музичної композиції. Крім названих трьох жанрів, Гайдн створив велику кількість ансамблів для різноманітних інструментальних комбінацій - від дуетів до октетів, а також інструментальні дивертисменти. В юні роки, до служби у князів Естергайзі, Гайдн теж створив немало інструментальних творів для різної кількості інструментів та різних жанрів. Серед них - ранні дивертисменти (концертино) для клавесину та струнних, які є зменшеною копією форм його майбутніх інструментальних концертів, ансамблі, а також перші симфонії та клавірні сонати.

На службі у П. А. Естергайзі, який утримував невеликого складу оркестр (струнний), композитор, крім написання музичних творів, виконував багато інших обов'язків, але отримав блискучу школу музиканта: йому часто доручалося керувати оркестром не тільки під час репетицій, але і на концертах. Склад оркестру змінився ще при житті першого капельмейстера Г. Вернера у 1766 році. Його новий роботодавець М. Й. Естергайзі у 1762 році збільшив склад музикантів капелу було розширено до 22 чоловік: оркестр налічував п'ять скрипок, віолончель, контрабас, флейту, два гобоя, два фаготи, дві валторни, орган, також в розпорядженні композитора були співаки-солісти, хористи.

Концерти для клавіру з оркестром Й. Гайдна - цікаве явище в його творчості. Композитор володів клавесином та скрипкою, а на службі у Естергайзі оволодів іншими інструментами (в тому числі улюбленим інструментом князя віолою ді бардоне - баритон, для якого він написав близько 140 сольних та ансамблевих творів). 3 усіх великих клавірних концертів, залишився тільки один автограф композитора - це концерт Соль мажор Hob XVIII:4, 1782. Стосовно решти концертів, в основному доведено його авторство (за непрямими ознаками, наприклад, концерт До мажор Hob XVIII:10, 1771 - в автографі зазначено Heyden). Проте $\epsilon$ концерти, авторство яких досі не визначено: концерт Ре мажор Hob XVIII:2, 1767 приписується Б. Галуппі, концерт До мажор Hob XVIII:5, 1763 приписується Г. К. Вагензейлю, крім того, концерт Фа мажор Hob XVIII:7, 1766 є перекладення фортепіанного тріо Hob XV:40, авторство якого теж приписують Г. К. Вагензейлю, концерти До мажор 
Hob XVIII: 8, 1766 та Фа мажор (для органа) Hob deest приписуються Л. Хофманну.

Майже всі концерти для клавіру були написані на службі князів Естергайзі, крім концерту До мажор Hob XVIII:1, 1756 та ранніх дивертисментів (концертино) для клавесину та струнних. Клавірні концерти та концертино чергуються в часі написання. Цікаві ансамблеві/оркестрові склади та варіанти сольних інструментів концертів та деяких концертино. В різних концертах композитором використовуються такі інструментальні склади та їх комбінації: для органа та струнного оркестру або тріо, для органу, струнних та духових (гобої, валторни, труби, можуть бути ще литаври), для клавесину та струнного оркестру або тріо, для клавесину, струнних та духових (гобої, валторни, труби, можуть бути ще литаври), для піанофорте (англійське фортепіано) та струнного оркестру або тріо, для піанофорте (англійське фортепіано), струнних та духових (гобої, валторни, труби, можуть бути ще литаври).

Майже всі концерти мають різні варіанти для виконання, тільки один варіант мають концерти клавесину та струнного оркестру Соль мажор Hob XVIII:9, Фа мажор Hob deest, Фа мажор Hob XVIII:F1, та концерт для органа та струнного оркестру Фа мажор Hob XVIII:F3. В сучасному виконавстві багатоваріантність в виборі сольних інструментів залишилася, додалось сучасне фортепіано. Особливою рисою гайдновських клавірних концертів $\epsilon$ те, що у виконанні різних сольних інструментів якість звучання не міняється, особливо між клавесином та піанофорте. Для Гайдна це не було принциповим, на відміну від Моцарта, не використовував клавесин в клавірних концертах (крім ранніх трьох).

Розширений оркестр князя М. Й. Естергайзі мав декілька клавішних інструментів, серед яких, ймовірно, було новітнє піанофорте. В якості сольних інструментів Гайдн використовував клавесин, піанофорте та орган, але, виходячи з того, що автографи не збереглися, можна тільки здогадуватися, яким був оригінал. Ймовірно, композитор передбачав виконання в різних сольних варіантах. Всі концерти, які мають такі варіанти, звучать на одному якісному рівні. Можливо, в органних концертах можна було б замінити сольний інструмент на клавесин або піанофорте, проте це доволі суб'єктивно. В деяких концертах зазначено у складі великий оркестр - мається на увазі розширений склад с посиленням оркестрових груп та введенням додаткових духових.

Б. Сабольчі в статті «Гайдн та угорська музика» аналізує наведені нижче твори композитора, який був постійно зв'язаний $з$ угорською 
культурою, живучи в князівських резиденція, особливо в літній. Він наводить приклади творів, в яких використовуються теми (як цитати або стилізації) не тільки угорського або циганського, але й польського, хорватського, турецького походження: «У творах 80-х і 90-х років Гайдн також користується угорськими темами, але розвиток їх досягає більш високого художнього рівня. Такі епізоди в повільній середній частині і в фіналі фортепіанної сонати ре мажор, (1780); в заключній частині «пташиного квартету» (1781) теж раптом виникає угорський епізод; ремажорний фортепіанний концерт і «велике» фортепіанне тріо соль мажор завершується розгорнутими жанровими фіналами в угорському дусі. Тi ж жанрові ознаки можна спостерігати в полонезі з фортепіанного тріо № 13 ля мажор, написаному наполовину «по-польськи», наполовину «поугорськи» [3, с. 78].

Серед клавірних концертів стилізація угорської тами $є$ в III частині концерту Ре мажор «Rondo all ungarese» Hob XVIII:11. Це тема рефрену, яка близька до танцю лапоцкаш. Цей танець походить з XVII ст. та має наступний вигляд: чоловіки та жінки оберталися по колу, пара танцює посередині кола. Поза колом чоловік чи жінка 3 лопаткою (дерев'яна дощечка з ручкою) переслідували одного з танцюристів, його не вдарять. I так по колу. Цей грайливий танець був популярним знатних дворів у Трансільванії. Цей танець Гайдн міг бачити безпосередньо у Естергайзі, адже князівський рід мав резиденції в декількох угорських землях, в тому числі у Трансільванії.

Клавірні концерти Й. Гайдна, які представляють лише частину його композиторської діяльності в концертному жанрі, користуються тими ж принципами організації оркестрової тканини, що і концерти для інших сколюючих інструментів. В. Акшенцева зауважує, що «створення Й.. Гайдном творів в різних жанрах, зокрема концертів, з використанням різноманітних інструментальних складів, 3 одного боку, відображає загальну тенденцію мобільності складів раннього класичного періоду, а 3 іншої - свідчить про активні пошуки та експерименти композитора в області інструментовки. Цьому сприяли різні сприятливі обставини, в тому числі професійні та матеріально-побутові» [1, с. 143]. Ймовірно, Гайдн мав можливості замовити інструменти та запросити музикантів (принаймні, донести свої побажання до Естергайзі). Це стосується i клавішних інструментів, серед які були i щипкові i молоточкові. Композитор мав в своєму розпорядженні орган, клавесин та піанофорте (хаммерклавір або фортепіано англійського зразка), про це пише в своїй статті «Гайдн та англійський класичний фортепіанний стиль» нідерландський клавесиніст та дослідник старовинної музики Б. ван Оорт 
[4]. Композитор мав максимальні умови для розвитку свого оркестрового стилю, справжній майданчик для експериментів та для відбору кращих зразків та прийомів, що і склали класичний віденський стиль.

\title{
Література:
}

1. Акшенцева В. М. Инструментальные концерты Й. Гайдна в контексте межжанровых взаимодействий. Манускрипт, 2019. Т. 12. В. 7. C. $140-144$. C. 143.

2. Любимов А., Мартынова О., Насонов Р. Клавесин и хаммерклавир: друзья-соперники? URL: http://www.earlymusic.ru/uploads/ cgmusic/id33/klavesin-hammerklavir.pdf

3. Сабольчи Б. Гайдн и Венгерская музыка. Советская музыка, 1959. № 6. С. $77-84$. с. 78.

4. Oort B. van Haydn and the English Classical Piano Style. Early music, 2000. Vol. 28. № 1. P. 73-89.

5. The History of the Piano. URL: https://www.piano-keyboardguide.com/history-of-the-piano.html

DOI https://doi.org/10.30525/978-9934-26-004-9-18

\section{КОНВЕРГЕНЦЯ І КУЛЬТУРА}

\author{
Уварова T. I. \\ кандидат мистецтвознавства, доиент, \\ дочент кафедри мистецтвознавства \\ та загальногуманітарних дисииплін \\ Міжнародного гуманітарного університету \\ м. Одеса, Україна
}

«Працювати з культурою після «культурного повороту» [1, с. 251] без розуміння основних тенденцій та процесів неможливо. Найважливіше поняття, яке описує дифузійні процеси в сучасній культурі - це «конвергенція». Цей термін достатньо широко застосовують у різноманітних сферах. «Конвергентність» (від лат. convergo) означає зближення, сходження до одного центру. Наприклад, у визначені «конвергентна еволюція», конвергенція розуміється як процес, що призводить до формування комплексу схожих ознак у представників неспоріднених груп. У біології, наприклад, конвергенція - це функція людського зору, яка дозволяє, дивлячись на об'єкт двома очима, 